\title{
On the Diurnal Variation of Atmospheric Potential Gradient in the Japan Archipelago*
}

\author{
by
}

\section{Hatakeyama}

\author{
Meteorological Research Institute \\ and M. Kawano \\ Electro-Technical Laboratory \\ (Received September 3, 1953)
}

\begin{abstract}
The diurnal variation of atmospheric potential gradient at eight stations in the Japan archipelago was investigated and the following results were obtained.

1) Times of occurrence of the maximum of diurnal and semidiurnal variation generally coincide with one another at stations of rural situation.

2) In larger cities the variation of the potential gradient is controlled mostly by the electrical conductivity of the lower stratum of the atmosphere.

3) In rural conditions only the semi-diurnal component of the variation of the potential gradient is controlled by the conductivity of the lower atmosphere and the diurnal component is controlled by a cause in the upper atmosphere.

4) The time of occurrence of the maximum of diurnal component of potential gradient in the Japan archipelago is 21 23 h, GMT.

5) The diurnal component of the potential gradient is composed of the unitary variation and the local time variation. The latter variation has a close relation with the character of weather around the station.
\end{abstract}

\section{Introduction}

It is well known among atmospheric electricians that the diurnal variation of the atmospheric potential gradient is composed of unitary variation (universal time

* Contribution to Geophysical Papers dedicated to Prof. M. HASfGAwa on his sixtieth birthday. 
variation) and local diurnal variation and that the observed mean curves of diurnal variation of atmospheric potential gradient show local differences. In this paper the authors tried to investigate the type of diurnal variation of atmospheric potential gradient observed at eight stations in Japan.

Longitudes and Latitudes of stations are shown in Table 1, and the localities of the stations are shown graphically in Fig. 1.

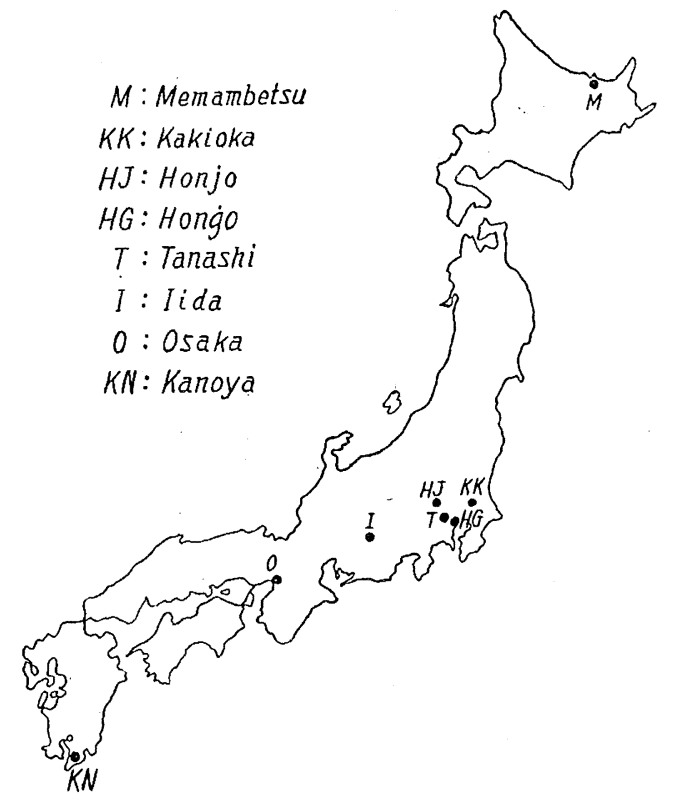

Table 1.

The latitudes and longitudes of stations.

\begin{tabular}{|c|c|c|c|c|}
\hline Station & \multicolumn{2}{|c|}{ Latitude } & \multicolumn{2}{|c|}{ Longitude } \\
\hline Memambetsu & $43^{\circ}$ & $55^{\prime} \mathrm{N}$ & $144^{\circ}$ & $12^{\prime} \mathrm{E}$ \\
\hline Honjo & 36 & 15 & 139 & 11 \\
\hline Kakioka & 36 & 14 & 140 & 11 \\
\hline Hongo & 35 & 40 & 139 & 45 \\
\hline Tanashi & 35 & 40 & 139 & 40 \\
\hline Iida & 35 & 31 & 137 & 50 \\
\hline Osaka & 34 & 39 & 135 & 33 \\
\hline Kanoya & 31 & 22 & 130 & 55 \\
\hline
\end{tabular}

Fig. 1. The localities of stations.

In the above, stations at Memambetsu, Kakioka and Kanoya are magnetic observatories, Honjo is a branch station of the Aerological Observatory and Osaka is a District Central Meteorological Observatory, all being attached to the Central Meteorological Observatory. Hongo signifies the Geophysical Institute of Tokyo University at Hongo, Tokyo, and Tanashi and Iida the branch stations of the Electro-Technical Laboratory. At these stations observation of atmospheric potential gradient has been made continuously or temporarily. Stations Memambetsı, Kakioka and Kanoya are situated in the country, Honjo, Tanashi. and Iida in the suburbs of town or large city and Hongo and Osaka in the central part of a large city respectively.

A radio-active collector or water-dropper and Benndorf's electrometer were used at these stations. Only at Hongo the deflection of mirror of a quadrant electrometer was photographically recorded on a bromide paper. In the present investigation results of observations on atmospheric-electrically calm days during 1949 and 1950 were used. 


\section{Results of Observations}

The diurnal variation of atmospheric potential gradient in summer and winter at Memambetsu, Kakioka, Hongo and Osaka is shown graphically in Fig. 2. At a glance we can find that the diurnal variation of atmospheric potential gradient in rural localities (as at Memambetsu and Kakioka) is remarkably different from that in urban localities (as at Hongo and Osaka).

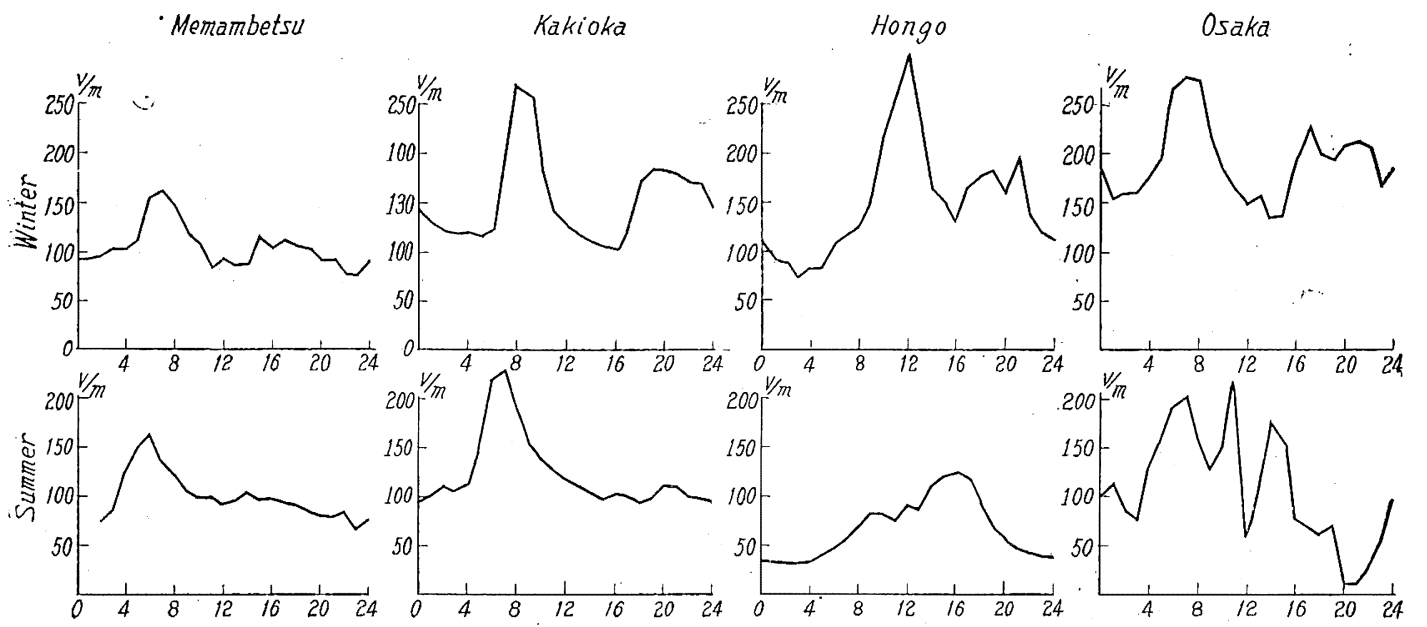

Fig. 2. The diurnal variation of atmospheric potential gradient.

We made the harmonic analysis of the diurnal variation of potential gradient at eight stations. Results of the analysis are shown in Table 2.

Table 2. The results of harmonic analysis of the diurnal variation of potential gradient.

\begin{tabular}{|c|c|c|c|c|c|c|}
\hline \multicolumn{2}{|l|}{ Station } & $\begin{array}{c}E_{0} \\
(\mathrm{~V} / \mathrm{m})\end{array}$ & $\begin{array}{c}\mathrm{E}_{1} / \mathrm{E}_{0} \\
(\%)\end{array}$ & $\begin{array}{l}\mathrm{E}_{2} / \mathrm{E}_{0} \\
(\%)\end{array}$ & $\begin{array}{c}\mathrm{T}_{1} \\
\text { (h. LMT) }\end{array}$ & $\begin{array}{c}\mathrm{T}_{2} \\
\text { (h. } \mathrm{LMT} \text { ) }\end{array}$ \\
\hline Memambetsu & $\left\{\begin{array}{l}\text { Summer } \\
\text { Winter }\end{array}\right.$ & $\begin{array}{r}98.2 \\
158.5\end{array}$ & $\begin{array}{l}22.3 \\
17.5\end{array}$ & $\begin{array}{l}19.1 \\
20.3\end{array}$ & $\begin{array}{l}8.0 \\
8.0\end{array}$ & $\begin{array}{l}6.0 \\
5.0\end{array}$ \\
\hline Honjo & $\left\{\begin{array}{l}\text { Summer } \\
\text { Winter }\end{array}\right.$ & $\begin{array}{r}86.1 \\
148.2\end{array}$ & $\begin{array}{l}59.5 \\
16.3\end{array}$ & $\begin{array}{r}9.4 \\
32.7\end{array}$ & $\begin{array}{l}8.1 \\
5.7\end{array}$ & $\begin{array}{l}7.1 \\
7.3\end{array}$ \\
\hline Kakioka & $\left\{\begin{array}{l}\text { Summer } \\
\text { Winter }\end{array}\right.$ & $\begin{array}{l}46.3 \\
78.0\end{array}$ & $\begin{array}{r}43.4 \\
6.4\end{array}$ & $\begin{array}{l}32.3 \\
34.0\end{array}$ & $\begin{array}{l}7.6 \\
7.3\end{array}$ & $\begin{array}{l}7.8 \\
8.0\end{array}$ \\
\hline Hongo & $\left\{\begin{array}{l}\text { Summer } \\
\text { Winter }\end{array}\right.$ & $\begin{array}{l}22.1 \\
50.4\end{array}$ & $\begin{array}{l}60.0 \\
32.5\end{array}$ & $\begin{array}{l}13.5 \\
27.0\end{array}$ & $\begin{array}{l}14.2 \\
13.7\end{array}$ & $\begin{array}{l}4.1 \\
9.2\end{array}$ \\
\hline Tanashi & $\left\{\begin{array}{l}\text { Summer } \\
\text { Winter }\end{array}\right.$ & $\begin{array}{r}95.0 \\
211.7\end{array}$ & $\begin{array}{l}36.6 \\
17.4\end{array}$ & $\begin{array}{l}23.0 \\
25.0\end{array}$ & $\begin{array}{l}9.2 \\
5.7\end{array}$ & $\begin{array}{l}7.7 \\
8.5\end{array}$ \\
\hline Iida & $\left\{\begin{array}{l}\text { Summer } \\
\text { Winter }\end{array}\right.$ & $\begin{array}{l}122.7 \\
151.7\end{array}$ & $\begin{array}{r}32.5 \\
6.2\end{array}$ & $\begin{array}{l}22.2 \\
34.0\end{array}$ & $\begin{array}{l}7.5 \\
7.3\end{array}$ & $\begin{array}{l}7.3 \\
8.7\end{array}$ \\
\hline Osaka & $\left\{\begin{array}{l}\text { Summer } \\
\text { Winter }\end{array}\right.$ & $\begin{array}{l}119.5 \\
192.8\end{array}$ & $\begin{array}{r}45.5 \\
7.7\end{array}$ & $\begin{array}{l}30.9 \\
24.0\end{array}$ & $\begin{array}{r}10.0 \\
6.0\end{array}$ & $\begin{array}{l}4.5 \\
7.3\end{array}$ \\
\hline Kanoya & Winter & 142.1 & 30.0 & 29.0 & 7.0 & 8.0 \\
\hline
\end{tabular}

In the above, $E_{0}$ denotes the mean value of the potential gradient, $E_{1}$ and $E_{2}$ 
the amplitude of the diurnal and the semi-diurnal component respectively and $T_{1}$ and $\mathrm{T}_{2}$ the local mean time at which the maximum of the diurnal and the semidiurnal component occurs respectively.

Inspecting Table 2, we find at once that times of occurrence of the maximum. of diurnal variation $\left(T_{1}\right)$ coincide with one another at six stations out of the eight in Table 2, the exceptions being Hongo and Osaka, and that times of occurrence of the maximum of semi-diurnal variation $\left(T_{2}\right)$ coincide with one another at all the stations in the table except that the times in summer at Hongo and Osaka are two or three hours earlier than at other stations.

It will be a remarkable fact that times of occurrence of the maximum of diurnal and semi-diurnal variation coincide with one another at several stations distributed from the northern tip of the Japan archipelago to the southern tip of it. The abnormal type of variation at Hongo and Osaka is considered to be due to the urban conditions around the stations. As to this point we will discuss more deeply in the next paragraph.

\section{Discussions}

It will be natural to consider that the abnormal type of variation at urban: stations has a relation with the turbidity in the lower atmosphere prevailing in a large city. Fortunately we have results of continuous observations of atmospheric electrical conductivity at Hongo, in the central part of Tokyo, and at Tanashi, in its suburbs. Results of the harmonic analysis of the variation of conductivity at the stations are shown in Table 3.

Table 3. The results of the harmonic analysis of the diurnal variation of conductivity.

\begin{tabular}{|c|c|c|c|c|c|}
\hline Station & $\lambda_{0}(10-6)$ & $\lambda_{1} / \lambda_{0}(\%)$ & $\lambda_{2} / \lambda_{0}(\%)$ & $\mathrm{T}_{1}($ h.LMT) & $\mathrm{T}_{2}($ h. LMT $)$ \\
\hline Hongo $\left\{\begin{array}{l}\text { Summer } \\
\text { Winter }\end{array}\right.$ & $\begin{array}{l}56.8 \\
54.5\end{array}$ & $\begin{array}{l}35.0 \\
30.0\end{array}$ & $\begin{array}{l}22.0 \\
14.0\end{array}$ & $\begin{array}{l}2.5 \\
2.0\end{array}$ & $\begin{array}{l}1.5 \\
0.6\end{array}$ \\
\hline Tanashi $\left\{\begin{array}{l}\text { Summer } \\
\text { Winter }\end{array}\right.$ & $\begin{array}{l}74.0 \\
64.0\end{array}$ & $\begin{array}{l}11.0 \\
14.5\end{array}$ & $\begin{array}{l}10.7 \\
22.0\end{array}$ & $\begin{array}{l}4.7 \\
5.5\end{array}$ & $\begin{array}{l}1.4 \\
1.8\end{array}$ \\
\hline
\end{tabular}

In the above, $\lambda_{0}$ denotes the mean value of the atmospheric electrical conductivity, $\lambda_{1}$ and $\lambda_{2}$ denote the diurnal and semi-diurnal component of the variation of conductivity respectively and $T_{1}$ and $T_{2}$ the local mean time at which the maximum of the diurnal and the semi-diurnal component occurs respectively.

Comparing the time of occurrence of maximum of the variation of conductivity in Table 3 with that of potential gradient in Table 2 we find that at Hongo the phase is reversed both in diurnal and semi-diurnal variation, while at Tanashi the phase is reversed in semi-diurnal variation, coinciding in diurnal variation.

From these results we can conclude that at Hongo, in the central part of the 
large city, the variation of the atmospheric electric potential gradient is controlled mostly by the electrical conductivity of the lower stratum of the atmosphere, and that, at Tanashi, in the suburbs of the large city, the semi-diurnal variation of the potential gradient is controlled by the conductivity of the lower atmosphere while the diurnal component of the variation of the potential gadient is controlled by some cause existing in the upper atmosphere.

On seeing Table 2 we may conclude generally that in the large city the variation of the potential gradient is controlled mostly by the electrical conductivity of the lower stratum of the atmosphere as at Hongo and Osaka and that in rural con. ditions only the semi-diurnal component of the variation of the potential gradient is controlled by the conductivity of the lower atmosphere, the diurnal component being controlled by some cause in the upper atmosphere. Of course the said cause also exists in the upper atmosphere over a large city but its effect is masked by the variation due to the causes near the earth's surface.

It is worthy of mention that the diurnal component of the potential gradient is composed of two parts, i.e. the unitary (universai time) variation and the local time variation. The time of occurrence of the maximum of diurnal component of potential gradient $\left(T_{1}\right)$ in Table 2 is $6 \sim 8 \mathrm{~h}, 135^{\circ} \mathrm{EMT}$, i. e. $21 \sim 23 \mathrm{~h}$, GMT. The time of occurrence of the maximum of the unitary variation in ocean and arctic region is $17 \sim 19 \mathrm{~h}$, GMT. There is a difference of a few hours.

For comparison's sake we made the harmonic analysis of the variation of potential gradient at foreign stations. Results are shown in Table 4.

Table 4. The results of the harmonic analysis of the diurnal variation of potential gradient at foreign stations.

\begin{tabular}{l|r|r|rr|r}
\hline \multicolumn{1}{c|}{ Station } & Latitude & Longitude & $\mathrm{T}_{1}$ (h. GMT) & $\mathrm{T}_{2}$ (h.GMT) \\
\hline Spitzbergen [1] & $79^{\circ} \mathrm{N}$ & $11^{\circ} \mathrm{E}$ & Year & 18 & 8 \\
College-Fairbanks [2] & $65^{\circ} \mathrm{N}$ & $148^{\circ} \mathrm{W}$ & $\left\{\begin{array}{l}\text { Summer } \\
\text { Winter }\end{array}\right.$ & 17 & 7 \\
Potsdam [1] & $52^{\circ} \mathrm{N}$ & $13^{\circ} \mathrm{E}$ & $\left\{\begin{array}{l}\text { Summer } \\
\text { Winter }\end{array}\right.$ & 7 & 9 \\
Batavia [3] & $6^{\circ} \mathrm{S}$ & $107^{\circ} \mathrm{E}$ & Year & 17 & 9 \\
Samoa [1] & $14^{\circ} \mathrm{S}$ & $172^{\circ} \mathrm{W}$ & Year & 23 & 18 \\
Christchurch [4] & $43^{\circ} \mathrm{S}$ & $172^{\circ} \mathrm{E}$ & Year & 16 & 9 \\
\hline
\end{tabular}

The time of occurrence of the maximum of diurnal variation of potential gradient $\left(\mathrm{T}_{1}\right)$ generally falls within $17 \sim 19 \mathrm{~h}$, GMT. The time of occurrence at Potsdam in summer and at Samoa do not follow the general tendency.

As is generally accepted, the unitary variation is caused by the variation of electric potential of the upper atmosphere. The variation of the electrical 
resistance of the air column extending from the upper atmosphere to the neigh. bourhood of the earth's surface causes the local diurnal variation. The latter variation has a close relation with the character of weather around the station.

By a harmonic analysis we cannot separate these two diurnal components from each other. We must subtract the unitary variation under appropriate assumptions. from an observed value to investigate the relation between the local diurnal component of the potential gradient and the character of weather around the station. In this direction the analysis of J. G. Brown[5] must be referred to.

Acknowledgement-In conclusion the authors wish to express their warmest thanks to the directors and members of observatories who sent observational materials at the authors' request.

\section{References}

[1] K̈̈HLER, K. 1929: Einführung in die atmosphärische Elektrizität, Berlin, Gebrüder Bornträger.

[2] Sherman, K.L. 1937: Atmospheric Electricity at College-Fairbanks Polar-Year Station. Terrestrial Magnetism and Atmospheric Electricity, 42, p. 371.

[3] Chauveau, B. 1922: Électricité atmosphérique, Paris, Librairie Octave Doin.

[4] Skey, H.F. 1930: Preliminary Report on Atmospheric Potential Gradient Observations at Christchurch, New Zealand, 1928-1929. Terrestrial Magnetism and Atmospheric Electricity, 35, p. 133.

[5] Brown, J. G. 1935: The Local Variaiion of the Earth's Electric Field. Terrestrial Magnetism and Atmospheric Electricty, 40, p. 413. 